\title{
Multi-Analytical Characterization of Slags to Determine the Chromium Concentration for a Possible Re-Extraction
}

\author{
Liesbeth Horckmans ${ }^{1, * \mathbb{C}}$, Robert Möckel ${ }^{2}$, Peter Nielsen ${ }^{1} \mathbb{C}$, Frantisek Kukurugya ${ }^{1}$, \\ Christine Vanhoof ${ }^{1}{ }^{\mathbb{D}}$, Agnieszka Morillon ${ }^{3}$ and David Algermissen ${ }^{3}$ \\ 1 Vlaamse Instelling voor Technologisch Onderzoek (VITO), Boeretang 200, 2400 Mol, Belgium; \\ peter.nielsen@vito.be (P.N.); fero.kukurugya@vito.be (F.K.); christine.vanhoof@vito.be (C.V.) \\ 2 Helmholtz-Zentrum Dresden-Rossendorf, Helmholtz Institute Freiberg for Resource Technology, \\ Chemnitzer Str. 40, 09599 Freiberg, Germany; r.moeckel@hzdr.de \\ 3 FEhS-Institut für Baustoff-Forschung e.V., Bliersheimer Str. 62, 47229 Duisburg, Germany; \\ a.morillon@fehs.de (A.M.); d.algermissen@fehs.de (D.A.) \\ * Correspondence: liesbeth.horckmans@vito.be
}

Received: 20 September 2019; Accepted: 16 October 2019; Published: 22 October 2019

\begin{abstract}
The CHROMIC project (effiCient mineral processing and Hydrometallurgical RecOvery of by-product Metals from low-grade metal contaIning seCondary raw materials) aims to recover chromium from steelmaking and ferrochrome slags to regain valuable resources and simultaneously reduce potential environmental impacts. To develop the recovery flowsheets and reliably calculate metal recovery, an accurate assessment of chromium concentration and distribution is essential. Therefore, model streams were thoroughly characterized using a combination of analytical techniques. In all materials, chromium is present in distinct but often small spinel phases, intergrown with other minerals and showing a considerable zonation in $\mathrm{Cr}$ content with higher amounts in the cores. The small size of the Cr-rich particles makes recovery by mineral processing challenging. Measured chromium content was found to differ largely based on the chemical dissolution method applied. The analysis of insoluble residues and comparison with a standard reference material evidenced that standard acid dissolution procedures based on $\mathrm{HCl} / \mathrm{HNO}_{3} / \mathrm{HBF}_{4}$ and $\mathrm{HNO} / 3 / \mathrm{HF} / \mathrm{H}_{2} \mathrm{O}_{2}$ are insufficient to fully dissolve spinel structures, leading to severe underestimations of chromium content. A sodium peroxide treatment is required for a full dissolution of spinels. This is noteworthy, since most of the legislation for the reuse of slags is currently based on acid dissolution methods.
\end{abstract}

Keywords: steel slag; ferrochromium slag; chromium extraction; multi-analytical characterization; method comparison

\section{Introduction}

Slags are an integral part of steel and ferrochrome ( $\mathrm{FeCr}$ ) production, as they capture impurities so that high-quality metals can be produced. Steelmaking slags are commonly divided into basic oxygen steelmaking (BOS or BOF), electric arc furnace (EAF), and ladle slags based on the method of production, as detailed in [1,2]. In Europe, 18.4 Mt of steelmaking slags were produced in 2016, of which $57 \%$ are BOS, $7.3 \%$ are EAF stainless steel slags (SS), and $25 \%$ are EAF carbon steel slags (CS) [3]. For ferrochrome, slag production varies according to the type of $\mathrm{FeCr}$ produced. High-carbon ferrochrome $(\mathrm{HC} \mathrm{FeCr})$ produces 1.1-1.6 tons slag/ton of metal [4,5] with an annual global production of $13 \mathrm{Mt} \mathrm{HC} \mathrm{FeCr}$ in 2018 [6]. Slag production is relatively higher for low-carbon ferrochrome (LC $\mathrm{FeCr}$ ) (2.4-2.5 tons of slag/ton metal), but the global annual production was only $0.9 \mathrm{Mt}$ in 2018 [6]. 
In Europe, steelmaking slags are used predominantly as aggregates in road construction (46\%), with smaller quantities used in metallurgy or as fertilizer. A smaller portion of slags is landfilled (14\%) or stored on site ( $8 \%$ ) [3]. In the USA, Japan, Germany, and France, the fraction of slag utilization has been close to $100 \%$, where $50 \%$ of slag has been used directly as a road base, with the remainder used for sintering and iron-making recycling. In contrast, the utilization of slags in China has been far more limited (22\% in 2012) [7].

While the majority of slags thus find a beneficial use, a minor portion is still landfilled, which is often due to volume instability associated with the presence of high free lime content or environmental issues due to heavy metal leaching [2].

Environmental issues, if any, are mostly linked to chromium, which is typically present in concentrations ranging from 1-2 wt \% for SS slags and 5-10 wt \% in HC FeCr slag [8]. Chromium (Cr) is commonly present in two oxidation states, namely $\mathrm{Cr}(\mathrm{III})$ and $\mathrm{Cr}(\mathrm{VI})$. The trivalent form, $\mathrm{Cr}(\mathrm{III})$, is a non-toxic, non-hazardous, essential trace element, whereas $\mathrm{Cr}(\mathrm{VI})$ is highly toxic and is classified as a hazardous material. The speciation not only affects toxicology, but also the mobility and availability of $\mathrm{Cr}$, with $\mathrm{Cr}(\mathrm{VI})$ compounds being much more mobile and bioavailable than the stable and almost insoluble $\mathrm{Cr}$ (III) compounds [9].

While $\mathrm{Cr}(\mathrm{VI})$ is a concern for human health and the environment, chromium is a valuable metal, and therefore, chromium-containing slags from steel production can be considered a secondary source of metal [10]. Johnson et al. [11] have estimated that (in 2000) $640 \mathrm{kt}$ of $\mathrm{Cr}$ were lost annually in $\mathrm{FeCr}$ slag, and $46 \mathrm{kt}$ of $\mathrm{Cr}$ were lost annually in stainless steel slags. Therefore, the recovery of $\mathrm{Cr}$ from slags is interesting for economic as well as environmental reasons.

Currently, the producers solely focus on the recovery of metallic particles, ignoring other chromium-bearing phases in the slag. Shen et al. [10] reported magnetic and gravity separation being performed on stainless steel slags to recover Cr. At Orbix NV in Belgium, stainless steel is recovered from SS slags by a treatment process based on size reduction, density, and magnetic separation. For carbon steel, the lower value of the recovered metal permits only less complicated treatment processes, e.g., using only magnetic separation. While a significant portion of Cr may be present in metallic particles dispersed throughout the slag, the majority of $\mathrm{Cr}$ is present in spinels [4]. Spinel phases are considered very stable and hardly contribute to the leaching of chromium from slags [12]. Promoting such spinel formation by the addition of iron and aluminum oxides in the liquid slag has proven to decrease the chromium leaching level [13].

Recent research has tried to recover non-metallic chromium also. Kim et al. $[14,15]$ investigated different processes to selectively recover chromium from stainless steel slags containing about 1.2 wt \% Cr. Alkali roasting with $\mathrm{NaOH}$ (0.67 mass ratio of $\mathrm{NaOH}$ to SS slag) followed by water leaching, achieved chromium leaching around $83 \%$ after roasting for $2 \mathrm{~h}$ at $400{ }^{\circ} \mathrm{C}$, with limited matrix dissolution [14]. Mechanical activation of the slag prior to roasting (dry milling at $400 \mathrm{rpm}$ for 15 min) could reduce the amount of $\mathrm{NaOH}$ required, while the addition of $\mathrm{NaNO}_{3}$ as an oxidant further increased $\mathrm{Cr}$ leaching to $89 \%$ [14]. Temperature-controlled extraction with $\mathrm{NaOH}$ in the presence of $\mathrm{NaOCl}$, followed by water leaching, resulted in a selective $\mathrm{Cr}$ leaching of $68 \%$ with minor dissolution of matrix materials [15]. Spooren et al. [16] demonstrated this process in a laboratory heap leaching setup for the selective leaching of $\mathrm{Cr}$ and $\mathrm{V}$ from FeCr and SS slags.

The Horizon2020 project CHROMIC (effiCient mineral processing and Hydrometallurgical RecOvery of by-product Metals from low-grade metal contaIning seCondary raw materials, www. chromic.eu) is a project funded by the European Union's Horizon 2020 Research and Innovation program under Grant Agreement no 730471. Running from 2016 until 2020, it wants to further investigate the potential for recovering $\mathrm{Cr}$ from slags by a combination of physical pre-treatment and hydrometallurgy. A thorough understanding of the chemical and mineralogical composition of the materials, and the degree of liberation is essential to properly devise the separation schemes, as well as accurately ascertain the selectivity and efficiency of the separation techniques. Typical investigation methods for all kinds of steel slags are X-ray diffraction (XRD; e.g., [17-19]), scanning electron 
microscopy (SEM; e.g., [19]), X-ray fluorescence (XRF; e.g., [20-22]), optical emission spectroscopy (ICP-OES; e.g., $[23,24])$, as well as other methods aiming at certain material characteristics, such as thermal analysis, infrared spectroscopy, CNS (carbon, nitrogen, sulfur) analysis, and others. In this article, we compare and evaluate different techniques (SEM, mineral liberation analysis (MLA), XRD, $\mathrm{XRF}$, wet chemical analysis) for their suitability to identify and quantify $\mathrm{Cr}$ and $\mathrm{Cr}$-rich phases. This multi-analytical approach is aimed at gaining in-depth knowledge about the way in which $\mathrm{Cr}$ is bound into the slags, which is indispensable to design a successful recovery process.

\section{Materials and Methods}

\subsection{Materials}

The following input materials were received from industrial partners:

- CS: Carbon steel EAF slags crushed to $<5 \mathrm{~mm}$

- SS: Fine fraction of stainless steel slags $(<0.5 \mathrm{~mm})$ (SS) resulting from a demetallization process

- LC FeCr: low-carbon ferrochrome slags ( $\mathrm{LC} \mathrm{FeCr}$ ), obtained from a single slag pot, crushed, and sieved to a fraction 4-9 $\mathrm{mm}$ for homogenization

- $\mathrm{HC}$ FeCr: high-carbon ferrochrome slags crushed and sieved to 0-4 mm

The samples were homogenized, and representative subsamples for the analyses were obtained by quartering until the proper sample size was reached. Where necessary, additional milling was performed using a disk and ball mill (see below).

\subsection{Methods for Chemical Composition}

X-ray fluorescence methods: The samples were also analyzed using a high-performance energy-dispersive XRF (EDXRF) spectrometer with polarized X-ray excitation geometry (XEPOS HE, Spectro Analytical Systems, Kleve, Germany) under He atmosphere. The instrument was equipped with a 50-W tungsten end window tube (maximum $60 \mathrm{kV}, 2 \mathrm{~mA}$ ) and a Silicon Drift Detector. The dried and finely ground $(<125 \mu \mathrm{m})$ samples were analyzed both as loose powder and as fused beads. For analysis as loose powder, an XRF sampling cup, provided with a $4-\mu \mathrm{m}$ prolene foil (Chemplex, Palm City, FL, USA), was filled with the sample and subsequently placed in the autosampler of the EDXRF system. The quantification was performed using a precalibrated software package (Spectro $\mathrm{X}$-LAB ${ }^{\text {Pro }}$ Version 5.1, Spectro Analytical Instruments, Kleve, Germany) for (semi)-quantitative analysis of geological materials. For bead analysis, all samples were ashed at $1000^{\circ} \mathrm{C}$ for $4 \mathrm{~h}$ in a muffle furnace (Thermolyne, Dubeque, IA, USA). About $0.9 \mathrm{~g}$ of ashed sample was subsequently mixed in a platinum crucible with a $100 \%$ lithiumtetraborate flux (XRF Scientific, Brussels, Belgium) in a flux:sample ratio of 10:1. The fusion was performed with an automatic fusion system (XrFuse 2, XRF Scientific, Brussels, Belgium), in which the sample was fused at $1250^{\circ} \mathrm{C}$ for $11 \mathrm{~min}$. An ammonium iodide tablet (XRF Scientific, Brussels, Belgium) was added as a release agent. The fused sample was removed from the furnace and poured into the pre-heated mold. During cooling, fan-forced air was applied to accelerate the solidification of the beads. For the XRF measurement, the fused bead sample was placed in the autosampler of the EDXRF system. The determination of the content of the bead samples was performed using an in-house developed calibration program.

Additional wavelength dispersive XRF (WDX-XRF) analyses were undertaken using a PANalytical Axios $^{\max }$ spectrometer (Malvern Panalytical, Kassel, Germany). The samples were ground to $<63 \mu \mathrm{m}$ and dried afterwards $\left(105^{\circ} \mathrm{C}\right)$ overnight. Then, $1 \mathrm{~g}$ of precalcined $\left(1 \mathrm{~h}\right.$ at $\left.950^{\circ} \mathrm{C}\right)$ sample material was mixed with $8 \mathrm{~g}$ of lithiumtetraborate $\left(99.5 \% \mathrm{Li}_{2} \mathrm{~B}_{4} \mathrm{O}_{7}+0.5 \% \mathrm{LiBr}\right.$, Claisse). The fully automated fusion furnace, the Ox advanced (Claisse, Malvern Panalytical, Kassel, Germany), was used to produce fused beads.

$\mathrm{HCl} / \mathrm{HNO}_{3} / \mathrm{HBF}_{4}$ dissolution: The metal content in the sample was determined with inductively coupled plasma atomic emission spectrometry (ICP-OES) after acid digestion using a microwave 
system. About $0.5 \mathrm{~g}$ of sample $(<125 \mu \mathrm{m})$ was weighed into the digestion vessel. Then, the following acids were separately added: $6 \mathrm{~mL}$ of $\mathrm{HCl}, 2 \mathrm{~mL}$ of $\mathrm{HNO}_{3}$, and $4 \mathrm{~mL}$ of $\mathrm{HBF}_{4}$. The digestion vessel was placed into the microwave unit (six positions, Milestone), and the following digestion process was applied: $2 \mathrm{~min}$ at $250 \mathrm{~W}, 2 \mathrm{~min}$ at $0 \mathrm{~W}, 5 \mathrm{~min}$ at $250 \mathrm{~W}, 5 \mathrm{~min}$ at $400 \mathrm{~W}$, and $5 \mathrm{~min}$ at $500 \mathrm{~W}$. At the end of the program, the vessels were cooled down to room temperature and transferred to a volumetric flask and filled up to $100 \mathrm{~mL}$ with ultrapure water. The digested solution was measured with an ICP-OES (Agilent 5100, Agilent Technologies Belgium, S.A., Diegem, Belgium) with an analytical error of 3\% (ICP-OES EN ISO 11885, 2009-09). The insoluble residue (IR) remaining in the digested solution was recovered by centrifugation and drying at $85{ }^{\circ} \mathrm{C}$ for $24 \mathrm{~h}$. A reference material (SARM 77 Ferrochrome slag, certified content of $12.5 \% \mathrm{Cr}_{2} \mathrm{O}_{3}(8.55 \% \mathrm{Cr})$ and $\left.5.31 \% \mathrm{Fe}\right)$ was analyzed for comparison.

$\mathrm{HNO}_{3} / \mathrm{HF} / \mathrm{H}_{2} \mathrm{O}_{2}$ dissolution: $\mathrm{HNO}_{3} / \mathrm{HF} / \mathrm{H}_{2} \mathrm{O}_{2}$ dissolution was analyzed according to DIN EN 13656, 2003-01): $100 \mathrm{mg}$ of sample was digested with $\mathrm{HNO}_{3}, \mathrm{HF}$, and $\mathrm{H}_{2} \mathrm{O}_{2}$ in a microwave (CEM Mars 6 or MLS Start) for $2 \times 20 \mathrm{~min}$, followed by 20 -min microwave digestion with $\mathrm{H}_{3} \mathrm{BO}_{3}$. The eluates were analyzed with ICP-OES, (Varian Vista MPX and Spectro Ciros), with an analytical error of $3 \%$ (ICP-OES EN ISO 11885, 2009-09).

Aqua regia composition (content excluding spinel phases): $250 \mathrm{mg}$ of sample was digested for $20 \mathrm{~min}$ in a microwave using aqua regia $\left(\mathrm{HNO}_{3}+3 \mathrm{HCl}\right)$. The eluates were analyzed with ICP-OES, with analytical error of $3 \%$.

Na-peroxide dissolution: About $0.1 \mathrm{~g}$ of sample was mixed in a $\mathrm{Zr}$ crucible together with $1.5 \mathrm{~g}$ of $\mathrm{Na}_{2} \mathrm{O}_{2}$ and $0.25 \mathrm{~g}$ of $\mathrm{Na}_{2} \mathrm{CO}_{3}$. The crucible was heated for $4 \mathrm{~min}$ in a muffle furnace at $560{ }^{\circ} \mathrm{C}$ (heating rate $8{ }^{\circ} \mathrm{C} / \mathrm{min}$ ). After cooling, the crucible was first rinsed with $40^{\circ} \mathrm{C}$ milli-Q water and then carefully reacted with $12.5 \mathrm{~mL}$ of concentrated $\mathrm{HNO}_{3}$ (suprapur). The resulting solution was made up to 100 $\mathrm{mL}$ with milli-Q water and measured with an ICP-OES (Agilent, 5100, with an analytical error of 3\% (ICP-OES EN ISO 11885, 2009-09)). A reference material (SARM 77 Ferrochrome slag, certified content of $12.5 \% \mathrm{Cr}_{2} \mathrm{O}_{3}(8.55 \% \mathrm{Cr})$ and $\left.5.31 \% \mathrm{Fe}\right)$ was analyzed for comparison.

\subsection{Mineralogy and Mineral Liberation}

Samples for XRD were wet (ethanol) milled down to approximately $4 \mu \mathrm{m}$ by means of a McCrone Mill (Retsch, Haan, Germany) using Y-stabilized $\mathrm{ZrO}_{2}$ grinding media. After drying, the samples were homogenized and prepared in a 27-mm sample holder. Measurements were conducted in a PANalytical Empyrean diffractometer (Malvern Panalytical, Kassel, Germany) equipped with a PIXcel 3Dmedipix area detector, an automatic divergence slit to provide constant irradiated area $\left(10 \times 12 \mathrm{~mm}^{2}\right)$, and a Co tube. Quantification was performed via the Rietveld method using the BGMN/Profex software package (v 3.12.0) [25]. X-ray powder diffraction on the IR after dissolution was carried out with a PANalytical Empyrean system operated at $40 \mathrm{kV}$ and $45 \mathrm{~mA}$, with Co tube (fine focus, $\lambda=1.7903 \AA$ ). Continuous scans with a step-size rate of $0.013^{\circ} / 49.725 \mathrm{~s}$ were performed within a $2 \theta$-range of $5^{\circ}-120^{\circ}$ (2D detector). The obtained diffractograms were qualitatively analyzed with the aid of HighScore Plus software (version 4.6a, Malvern Panalytical B.V., Almelo, the Netherlands).

For SEM-EDX (Scanning Electron Microscopy-Energy Dispersive X-ray Spectroscopy) analysis, the samples were embedded in a low-viscosity epoxy resin and gradually polished down to $\frac{1}{4}-\mu \mathrm{m}$ diamond powder grit size. The samples were coated with Pt-Pd prior to microscopic analysis. Morphological observations were carried out by an SEM microscope FEI NOVA NANOSEM 450 (FEI, Brno, Czech Republic) with EDX analyzer BRUKER QUANTAX 200 (Bruker, Mannheim, Germany) with SDD detector.

Mineral liberation analysis (MLA) samples include two grain mounts of each slag sample, each prepared in epoxy resin, one cut after solidification perpendicular to the mount and prepared again in 25-mm mounts. This procedure compensates for gravimetric effects and therefore distortion [26]. Samples were carbon coated. An FEI Quanta 650F MLA-FEG system (FEI MLA Software Suite 3.14; FEI, Hilsboro, OR, USA) was used for the subsequent investigation. 


\section{Results}

\subsection{Chemical Composition}

Table 1 shows the main components of the materials, as an average of the different XRF measurements methods. Overall, for the major elements, the difference between measurements is limited (standard deviation is low). The results show that the chemical composition of LC FeCr and $\mathrm{SS}$ is quite similar, with $\mathrm{Ca}, \mathrm{Mg}$, and $\mathrm{Si}$ as the main elements. CS has a much higher $\mathrm{Fe}_{2} \mathrm{O}_{3}$ content and lower $\mathrm{CaO}$ and $\mathrm{SiO}_{2}$ content, whereas for $\mathrm{HC} \mathrm{FeCr}$, the main elements are $\mathrm{Al}, \mathrm{Mg}$, and Si. Chromium concentration is also significantly higher in $\mathrm{HC} \mathrm{FeCr}$ than in the other materials.

Table 1. Main components (average \pm standard deviation, in wt $\%$, as measured by $\mathrm{X}$-ray fluorescence (XRF) analyses).

\begin{tabular}{ccccc}
\hline Component & CS & LC FeCr & HC FeCr & SS \\
\hline $\mathrm{Al}_{2} \mathrm{O}_{3}$ & $8.1 \pm 0.3$ & $7.2 \pm 0.6$ & $25.9 \pm 0.3$ & $4.2 \pm 0.5$ \\
$\mathrm{CaO}$ & $20.4 \pm 1.9$ & $43.0 \pm 2.9$ & $1.7 \pm 0.0$ & $45.1 \pm 2.6$ \\
$\mathrm{Fe}_{2} \mathrm{O}_{3}$ & $42.9 \pm 5.2$ & $0.4 \pm 0.2$ & $6.8 \pm 1.9$ & $0.8 \pm 0.1$ \\
$\mathrm{MgO}$ & $3.4 \pm 1.3$ & $14.0 \pm 1.8$ & $25.5 \pm 5.0$ & $10.9 \pm 1.8$ \\
$\mathrm{MnO}$ & $5.6 \pm 0.5$ & $0.10 \pm 0.01$ & $0.3 \pm 0.1$ & $1.1 \pm 0.2$ \\
$\mathrm{SiO}_{2}$ & $9.9 \pm 0.2$ & $30.3 \pm 2.9$ & $28.0 \pm 1.5$ & $30.8 \pm 5.6$ \\
$\mathrm{Cr}_{2} \mathrm{O}_{3}$ & $3.6 \pm 0.5$ & $4.6 \pm 0.5$ & $10.1 \pm 1.9$ & $3.3 \pm 0.7$ \\
\hline
\end{tabular}

\subsection{Mineralogy}

Results of the XRD investigation for CS, LC FeCr, HC FeCr, and SS are compiled in Table 2. Depending on the specific slag, the modal mineralogy and the contents differ quite a lot. Especially the spinel contents - as well as their chemical composition-differs from slag to slag. The dominating spinel in the CS slag is a Mg-Fe-containing spinel (magnesioferrite, $\mathrm{MgFe}_{2} \mathrm{O}_{4}$ ) with $17 \mathrm{wt} \%$ content, followed by magnetite $\left(\mathrm{Fe}_{3} \mathrm{O}_{4}\right)(\sim 5 \mathrm{wt} \%)$ and minor contents of magnesiochromite $\left(\mathrm{MgCr}_{2} \mathrm{O}_{4}\right)(\sim 3 \mathrm{wt} \%)$. In contrast, the spinels of the LC slag contain no or very little $\mathrm{Fe}$, and the main spinel phase is an Mg-rich chromite $\left(\mathrm{MgCr}_{2} \mathrm{O}_{4} \sim 7 \mathrm{wt} \%\right)$. The same appears for the SS slag with $\mathrm{MgCr}_{2} \mathrm{O}_{4}$ being the main spinel phase ( $6 \mathrm{wt} \%)$. In the $\mathrm{HC}$ FeCr slag, both a dominant chromium-rich $\left((\mathrm{Fe}, \mathrm{Mg}) \mathrm{Cr}_{2} \mathrm{O}_{4}\right.$, $\sim 35 \mathrm{wt} \%$ ) and a magnesiospinel $(\mathrm{Mg}, \mathrm{Fe})(\mathrm{Al}, \mathrm{Cr})_{2} \mathrm{O}_{4}$ can be found. The high $\mathrm{MgO}$ values (see Table 1) of the $\mathrm{HC}$ FeCr slag can be explained by the high percentage of $\mathrm{Mg}$ silicates (forsterite and enstatite).

Back-calculated chemical information shows good correlation to the chemical compositions of at least the major elements, proving the consistency of the data. Only the stainless steel slag reveals a slight underestimation of Al-rich phases (sum $2.6 \mathrm{wt} \% \mathrm{Al}_{2} \mathrm{O}_{3}$ ) and a corresponding overestimation of $\mathrm{CaO}$ (sum $49.0 \mathrm{wt} \%$ ). The most likely reason is that phases with varying composition (spinels, gehlenite-akermanite) lead to a peak broadening that is compensated by different physical effects (line broadening due to stress), but does not reflect the actual chemical diversity (leading to overlapping peaks, with similar resulting peak shape). This could be overcome by using a respective number of correct structure models - which in turn needs the correct chemical composition for each single one of the individual minerals. Since the quantification of mineral (groups) led to comparable results and other main components $\left(\mathrm{SiO}_{2} 30.0 \mathrm{wt} \%\right.$ and $\mathrm{MgO} 10.0 \mathrm{wt} \%$ from XRD, respectively, cf. Table 1) fit quite well in our case, we considered these mineralogical data as close to perfect, even without the corresponding chemical accordance for $\mathrm{Al}$ and $\mathrm{Ca}$. 
Table 2. Results from X-ray diffraction (Rietveld method), showing the mineral phases within the slags (crystalline parts only, values given in wt \%); for details about the spinels, see the text. CS: carbon steel slags, LC FeCr: low-carbon ferrochrome, HC FeCr: high-carbon ferrochrome, SS: stainless steel slags.

\begin{tabular}{|c|c|c|c|c|}
\hline Phase & CS & $\mathrm{LC} \mathrm{FeCr}$ & $\mathrm{HC} \mathrm{FeCr}$ & SS \\
\hline Spinels (diff. compositions) & $26.7 \pm 2.3$ & $15.4 \pm 0.6$ & $43.3 \pm 3.9$ & $6.4 \pm 0.4$ \\
\hline Quartz $\left(\mathrm{SiO}_{2}\right)$ & $0.5 \pm 0.2$ & $0.3 \pm 0.1$ & $1.5 \pm 0.6$ & $0.5 \pm 0.2$ \\
\hline Calcite $\left(\mathrm{CaCO}_{3}\right)$ & $0.8 \pm 0.2$ & $1.8 \pm 0.3$ & - & $7.6 \pm 0.6$ \\
\hline Wuestite (FeO) & $31.8 \pm 0.4$ & - & - & - \\
\hline Hematite $\left(\mathrm{Fe}_{2} \mathrm{O}_{3}\right)$ & $4.0 \pm 0.9$ & - & - & - \\
\hline Periclase $(\mathrm{MgO})$ & - & $2.7 \pm 0.2$ & - & $4.1 \pm 0.6$ \\
\hline Dicalciumsilicate (" $\left.\mathrm{C}_{2} \mathrm{~S}^{\prime \prime}\right)$ & - & - & - & $13.9 \pm 1.0$ \\
\hline Cuspidine $\left(\mathrm{Ca}_{4} \mathrm{Si}_{2} \mathrm{O}_{7} \mathrm{~F}_{2}\right)$ & - & - & - & $14.9 \pm 0.7$ \\
\hline Larnite $\left(\mathrm{Ca}_{2} \mathrm{SiO}_{4}\right)$ & $17.8 \pm 0.5$ & $6.3 \pm 0.5$ & - & $1.9 \pm 0.4$ \\
\hline Wollastonite $\left(\mathrm{CaSiO}_{3}\right)$ & - & - & - & $1.0 \pm 0.3$ \\
\hline Enstatite $\left(\mathrm{Mg}_{2} \mathrm{Si}_{2} \mathrm{O}_{6}\right)$ & - & - & $28.5 \pm 1.1$ & - \\
\hline Forsterite $\left(\mathrm{Mg}_{2} \mathrm{SiO}_{4}\right)$ & - & - & $16.7 \pm 0.9$ & - \\
\hline Akermanite $\left[\mathrm{Ca}_{2}(\mathrm{Al}, \mathrm{Mg})(\mathrm{Al}, \mathrm{Si}) \mathrm{O}_{7}\right]$ & - & - & - & $9.8 \pm 0.6$ \\
\hline Gehlenite $\left[\mathrm{Ca}_{2} \mathrm{Al}\left(\mathrm{AlSiO}_{7}\right)\right]$ & $14.8 \pm 0.4$ & $3.4 \pm 0.4$ & - & - \\
\hline Brownmillerite $\mathrm{Ca}_{2}(\mathrm{Al}, \mathrm{Fe})_{2} \mathrm{O}_{5}$ & $3.8 \pm 0.2$ & - & - & - \\
\hline Merwinite $\left[\mathrm{Ca}_{3} \mathrm{Mg}\left(\mathrm{SiO}_{4}\right)_{2}\right]$ & - & $47.5 \pm 0.6$ & - & $24.0 \pm 0.8$ \\
\hline Bredigite $\left[\mathrm{Ca}_{14} \mathrm{Mg}_{2}\left(\mathrm{SiO}_{4}\right)_{8}\right]$ & - & $22.7 \pm 0.6$ & - & $16.0 \pm 0.9$ \\
\hline
\end{tabular}

\subsection{SEM and MLA}

While XRD yielded valuable information about the mineralogical composition, it is not possible to obtain a detailed view on $\mathrm{Cr}$ distribution, as the $\mathrm{Cr}$-containing phases are only a minority among the different minerals present, and are therefore difficult to isolate. SEM-based techniques were applied to gain a deeper insight into the $\mathrm{Cr}$ distribution in the phases (mainly in the spinels) and the characteristics of the grains themselves.

SEM analysis confirms the findings of XRD that the main phases of the CS slags are $\mathrm{Ca}(\mathrm{Al})$ silicates (larnite, gehlenite) and Fe oxides, including Fe-based spinel phases (magnetite, Fe-Mg spinel), which are difficult to distinguish from each other. The minerals are intergrown at small scale $(<100 \mu \mathrm{m})$, with the Cr-rich spinels being 10-100 $\mu \mathrm{m}$ in size (Figure 1). Figure 2 shows that the chromium is unevenly distributed within the spinels, with clear enrichment in distinct zones.

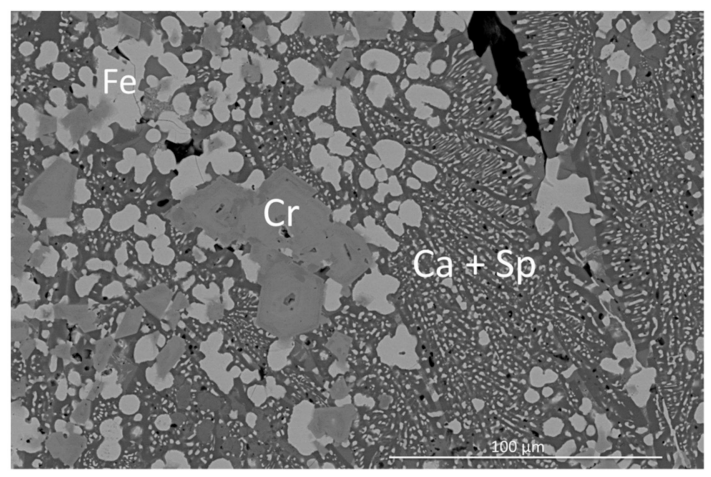

(a)

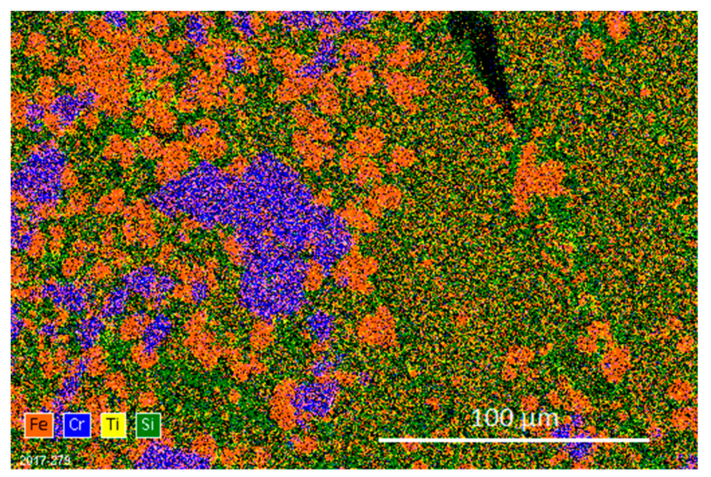

(b)

Figure 1. (a) SEM-BSE (back scattered electrons) image of $\mathrm{CS}$ slags. $\mathrm{Ca}=\mathrm{Ca}(\mathrm{Al})$-silicates (larnite, gehlenite) (dark grey), $\mathrm{Fe}=\mathrm{Fe}$ oxides (wuestite, Fe spinel), $\mathrm{Sp}=\mathrm{Mg}-\mathrm{Al}$ spinel, $\mathrm{Cr}=\mathrm{Mg}$ chromite. Different minerals are intergrown at small (10-100 $\mu \mathrm{m})$ scale. (b) Element distribution as determined by EDX, showing the presence of $\mathrm{Cr}$ in selected spinels. 


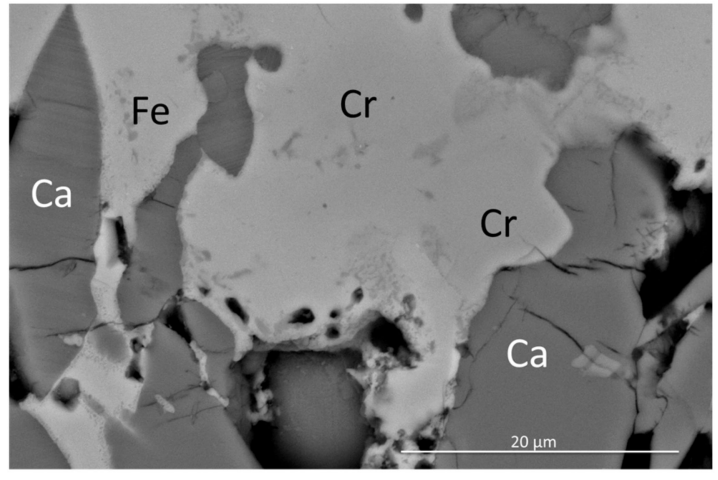

(a)

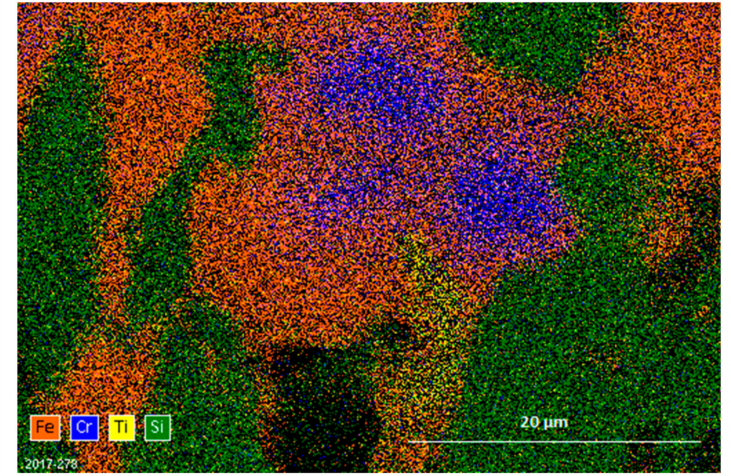

(b)

Figure 2. SEM-BSE image of CS slags. $\mathrm{Ca}=\mathrm{Ca}(\mathrm{Al})$ silicates (larnite, gehlenite), $\mathrm{Fe}=\mathrm{Fe}$ oxides (wustite, Fe spinel), $\mathrm{Cr}=\mathrm{Mg}$ chromite. (a) BSE image of Fe-rich spinel with Cr-rich spinel inclusions in the matrix of $\mathrm{Ca}(\mathrm{Al})$ silicates. (b) Element distribution determined by EDX.

The SEM-EDX analysis of the LC FeCr slags shows that the matrix consists of elongate CaMg silicates (merwinite, bredigite) intergrown with spinels in diffuse veins and on their edges (Figure 3). Small (20-40 $\mu \mathrm{m})$ metallic ferrochrome particles are spread out diffusely over the material. Chromium is present in the FeCr particles, and in the spinel phases.

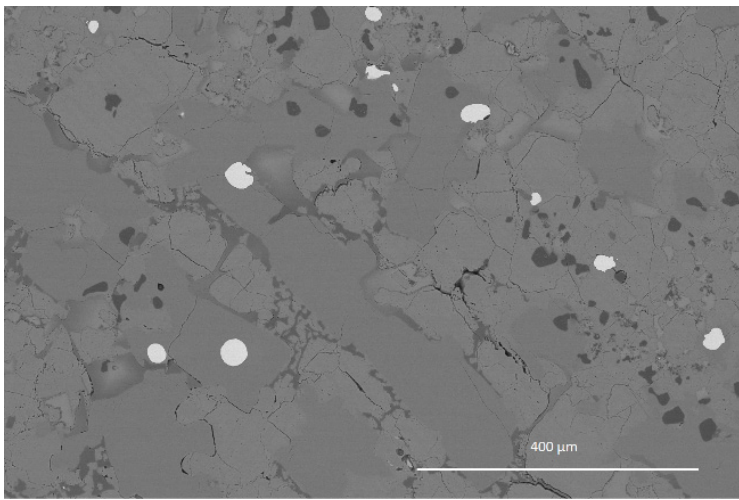

(a)

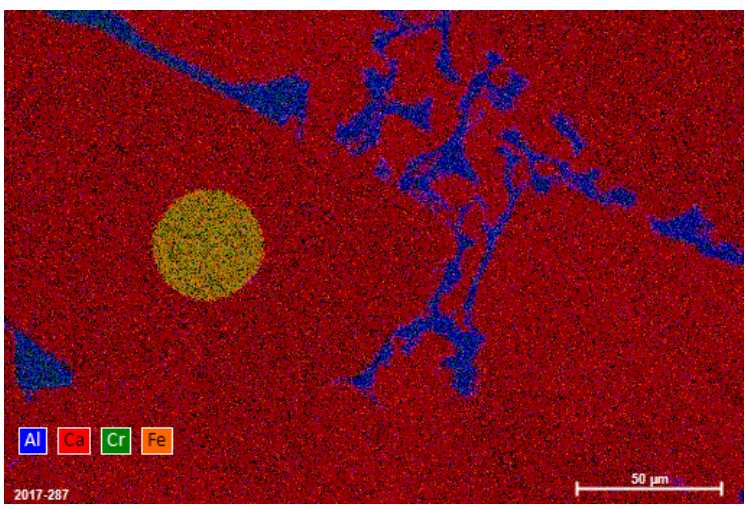

(c)

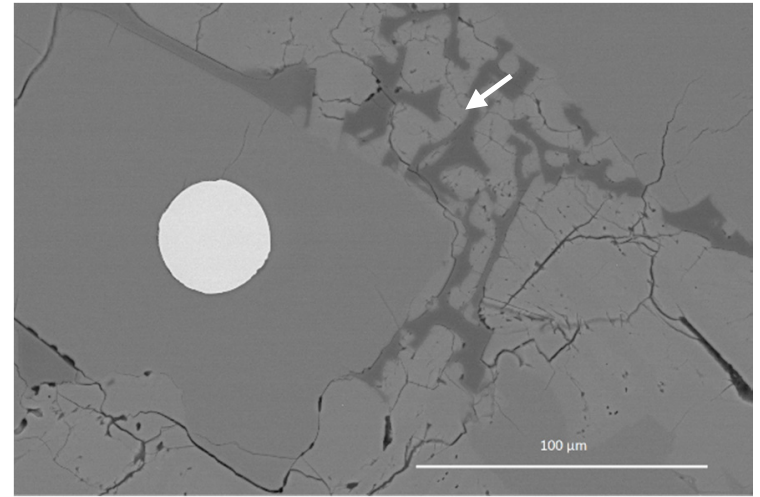

(b)

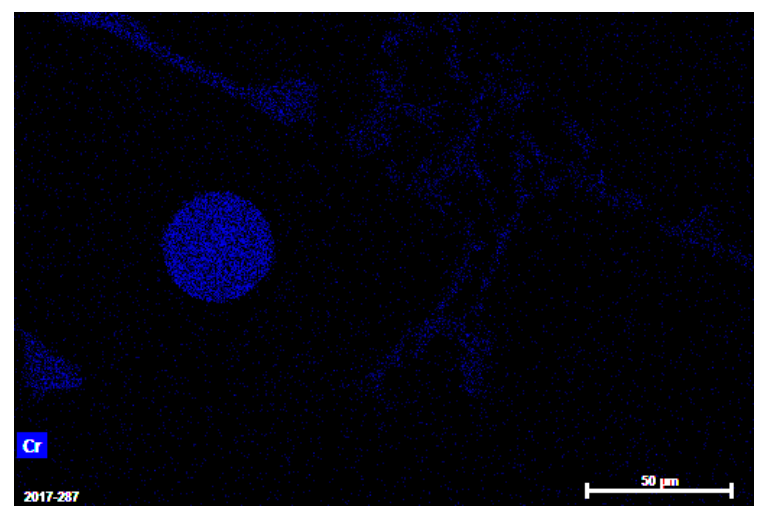

(d)

Figure 3. (a) SEM-BSE image of LC FeCr slags showing FeCr metal (white particles) in a matrix of elongated CaMg silicates with veins of spinels. (b) Detailed view of CaMg silicate with embedded FeCr particles surrounded by a spinel (arrow). (c) Main element distribution map determined by EDX. (d) $\mathrm{Cr}$ distribution as measured by EDX, showing $\mathrm{Cr}$ in FeCr particles and spinels. 
As shown in Figure 4, HC FeCr metal particles are well liberated and typically larger than in the LC FeCr sample (up to $500 \mu \mathrm{m}$ ), although smaller droplets are also present. Besides the Fe-Cr metal particles, chromium is also present in different spinel forms, as confirmed by XRD. The chromium content differs between regions in the metal (Figure 4) and spinel (Figure 5) particles.

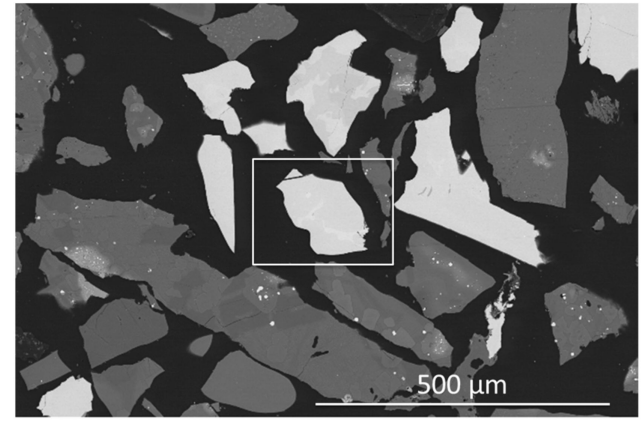

(a)

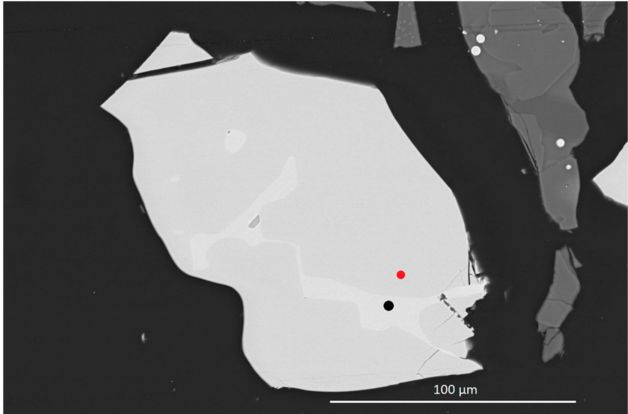

(b)

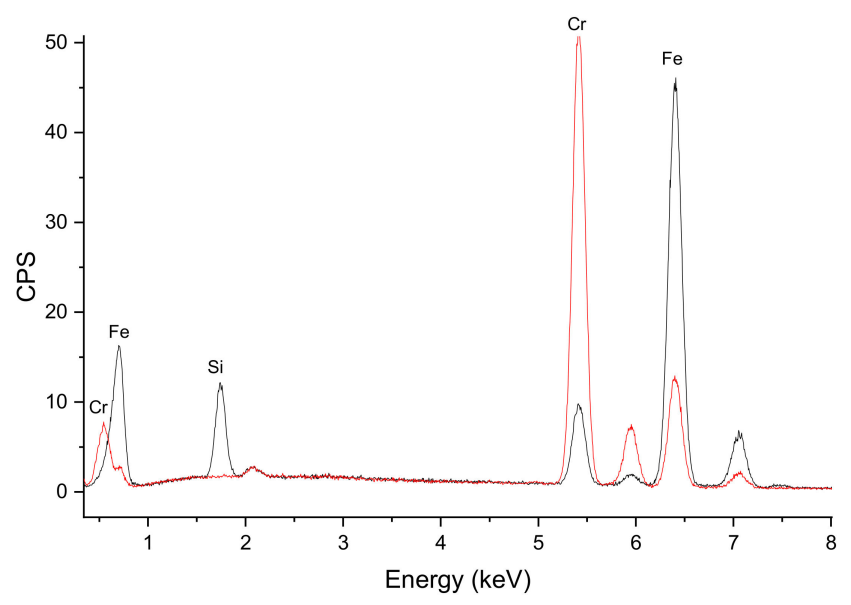

(c)

Figure 4. SEM-BSE image of HC FeCr slags. (a) Dark grey silicate slag particles and light-colored FeCr metal particles grains. (b) Detail of FeCr metal grain, with indication of EDX measurement locations (colored circles). Darker areas in the metal particle contain more chromium, as shown by EDX measurements in (c).

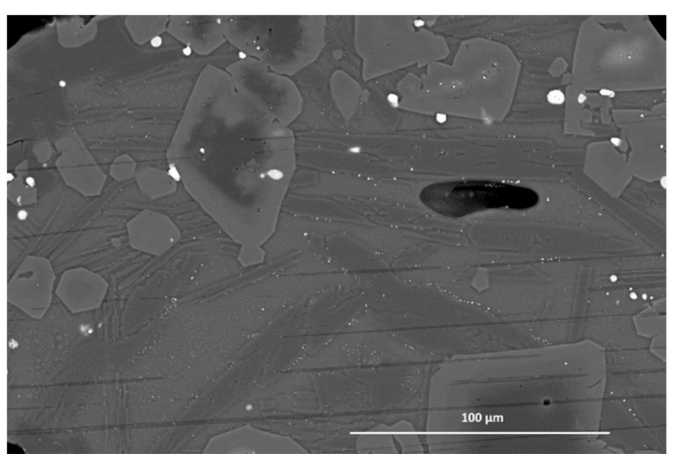

(a)

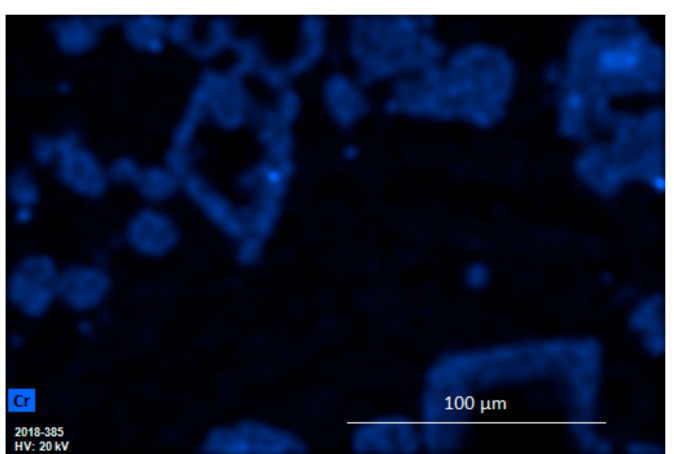

(b)

Figure 5. (a) SEM-BSE image of $\mathrm{HC}$ FeCr slags showing zoned $\mathrm{Mg}(\mathrm{Cr}, \mathrm{Al})_{2} \mathrm{O}_{4}$ spinel crystals with a Al-rich core and $\mathrm{Cr}$-rich border in a matrix of elongated (dark) enstatite $\left(\mathrm{MgSiO}_{3}\right)$ crystals, with small FeCr metal particles (white spots). (b) EDX Cr distribution map showing the presence of $\mathrm{Cr}$ in the spinel outer rims and metal particles. 
SEM-EDX analysis of the SS samples shows that the matrix consists of CaMg silicates (merwinite, bredigite), Ca silicates (larnite, cuspidine), and CaMgAl silicates (akermanite) (Figure 6 combined with Table 2). Overall, the material contains many very fine particles, but also some composite grains. Small metallic stainless steel particles are present, which are mostly $<5 \mu \mathrm{m}$ in size. Chromium is present within these metallic particles, and also in distinct magnesiochromite spinel phases $(10-30 \mu \mathrm{m})$.

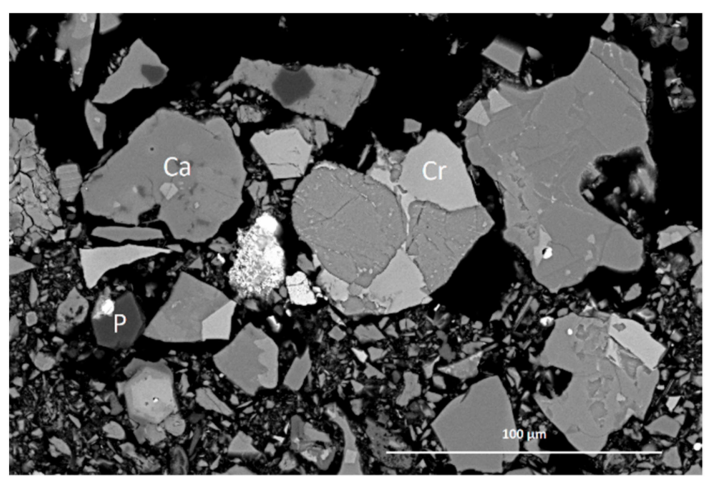

(a)

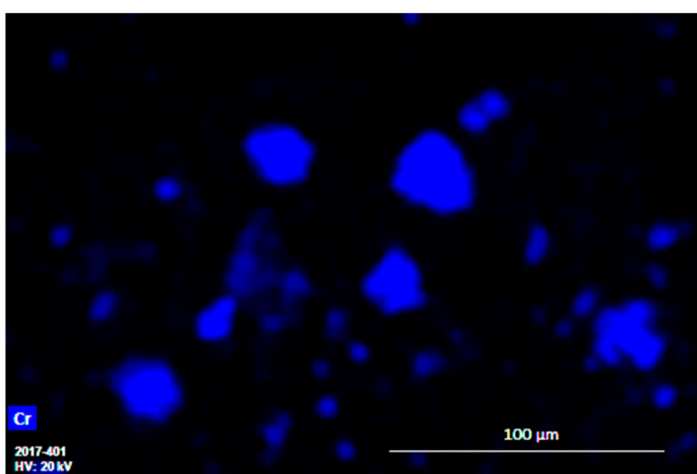

(b)

Figure 6. (a) SEM-BSE image of the SS slag showing $\mathrm{Ca}, \mathrm{CaMg}$, and $\mathrm{CaMgAl}$ silicates (grey, $\mathrm{Ca}$ ), periclase (dark grey, $\mathrm{P}$ ), and $\mathrm{Cr}$-rich spinel (magnesiochromite, light grey, $\mathrm{Cr}$ ). The bright white particle is stainless steel. (b) EDX Cr distribution map showing that $\mathrm{Cr}$ is present in magnesiochromite, and in lower concentrations in the metal.

MLA (mineral liberation analysis) gives the opportunity to determine particle size distributions of both whole sample and prechosen phases (grains), and additional grain characteristics such as liberation, association, etc. Figure 7 illustrates the assignment of a backscattered electron (BSE) image to the false-colored phase-distinguishing image of mineral liberation analysis, derived from the combination of image analysis (grey values) and EDX spectra. Chromium-rich phases in the particles can be clearly determined. Figure 8 gives the summarized grain size distribution of $\mathrm{Cr}$-rich phases. The Cr-rich phases (mainly $\mathrm{Cr}$-rich spinel phases) in the different samples reveal quite similar and small grain sizes, with the majority of $\mathrm{Cr}$ particles below $100 \mu \mathrm{m}$. The only exception is the $\mathrm{HC} \mathrm{FeCr}$, which has significantly larger particle sizes. In general, the results from SEM analyses were confirmed, and the grain size distribution for all Cr-containing phases were achieved from the MLA data (see Figure 7).
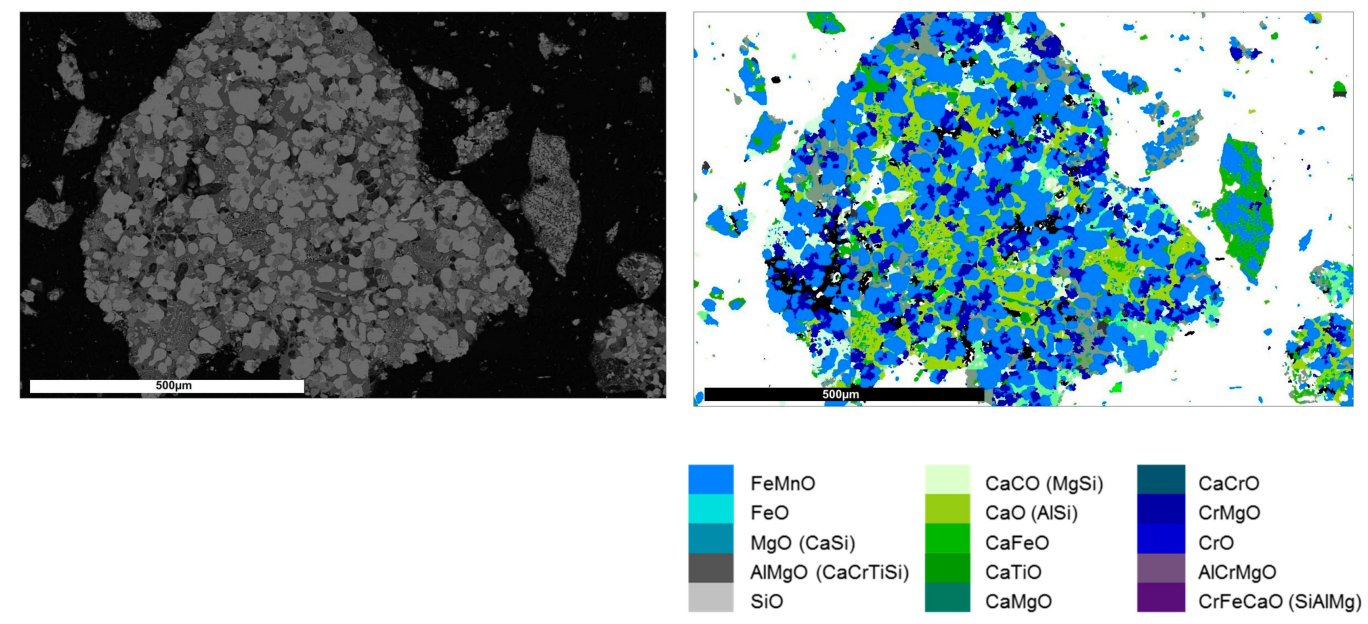

(a)

(b)

Figure 7. Illustration of mineral liberation analysis (MLA). (a): BSE and (b): color-coded picture of particles from the CS slag sample. 


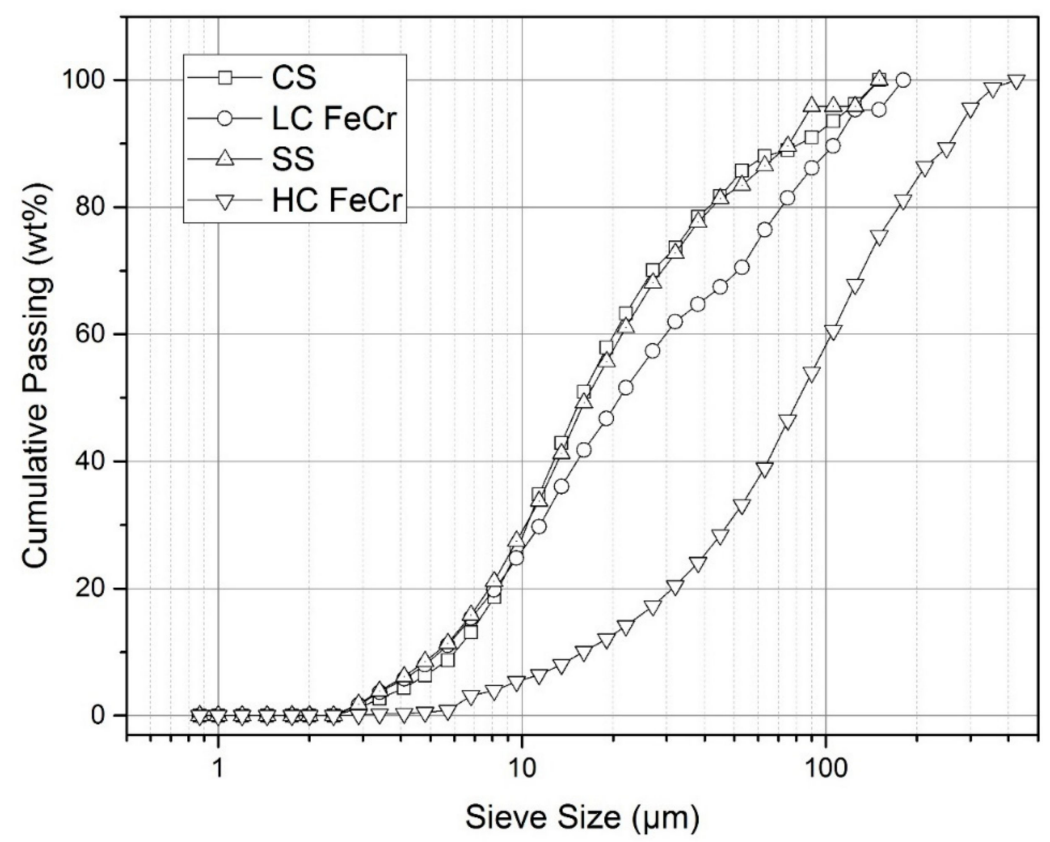

Figure 8. Particle size distribution of the Cr-containing grains in the slags as determined by MLA. It can be seen clearly that the Cr-containing phases of the CS, LC, and SS slags show a similar distribution, whereas the grains of the $\mathrm{HC}$ are much larger.

\subsection{Chromium Quantification}

Table 3 compares the $\mathrm{Cr}$ content of the materials as determined by the different wet chemical analyses. Although the individual methods show good reproducibility (low standard deviation), there is clearly a significant difference in the amount of $\mathrm{Cr}$ that is liberated.

Table 3. Comparison of $\mathrm{Cr}$ content (in wt \%) between wet chemical methods. Results show average \pm standard deviation.

\begin{tabular}{ccccc}
\hline Material & Aqua Regia & $\mathbf{H C l} / \mathrm{HNO}_{3} / \mathbf{H B F}_{\mathbf{4}}$ & $\mathbf{H N O}_{3} / \mathbf{H F}_{\mathbf{H}} \mathbf{H}_{\mathbf{2}} \mathbf{O}_{\mathbf{2}} / \mathbf{H}_{\mathbf{3}} \mathbf{B O}_{3} \mathbf{N a}$ Peroxide \\
\hline $\mathrm{CS}$ & $0.50 \pm 0.02$ & $0.99 \pm 0.09$ & $2.33 \pm 0.20$ & $2.59 \pm 0.06$ \\
$\mathrm{LC} \mathrm{FeCr}$ & $0.34 \pm 0.02$ & $1.08 \pm 0.11$ & $1.10 \pm 0.18$ & $3.21 \pm 0.07$ \\
$\mathrm{HC} \mathrm{FeCr}$ & $4.00 \pm 0.91$ & $5.72 \pm 0.05$ & $11.2 \pm 0.69$ & $16.60 \pm 0.28$ \\
SS & $0.23 \pm 0.001$ & $0.52 \pm 0.13$ & $0.86 \pm 0.4$ & $2.54 \pm 0.05$ \\
SARM 77 & n.a. & $3.43 \pm 0.54$ & n.a. & $7.78 \pm 0.27$ \\
\hline
\end{tabular}

n.a.: not analyzed.

The Na-peroxide dissolution method, commonly applied in the ferrochrome industry for the analysis of $\mathrm{Cr}$ ores and $\mathrm{FeCr}$ slags, gives the highest recovery, with $91 \%$ of $\mathrm{Cr}$ recovered from the SARM 77 reference material. This method is not regularly applied in analytical laboratories outside the ferrochrome industry, and is not well known for the analysis of secondary resources.

Moreover, legislation often refers to other, more traditional methods of destruction. For example, the $\mathrm{HCl} / \mathrm{HNO}_{3} / \mathrm{HBF}_{4}$ dissolution method is the standard destruction method foreseen in the "Compendium for Sampling and Analysis" that must be used in the Flemish Environmental Legislation.

Therefore, it is highly relevant to evaluate their performance. It is clear that both these methods $\left(\mathrm{HCl} / \mathrm{HNO}_{3} / \mathrm{HBF}_{4}\right.$ and $\mathrm{HNO} / \mathrm{HF} / \mathrm{H}_{2} \mathrm{O}_{2} / \mathrm{H}_{3} \mathrm{BO}_{3}$ ) only liberate a portion of the $\mathrm{Cr}$ that is present, although both are considered to represent the "total content".

Aqua regia dissolution is known to liberate only metals not included in spinels [27]. Based on the aqua regia results, it is apparent that only a minor fraction of the $\mathrm{Cr}(10-20 \%)$ is present in minerals outside spinels, part of which may be the metallic fraction. 
To better understand the underestimation by the acid dissolution methods, the insoluble residues (IR) that remained after the $\mathrm{HCl} / \mathrm{HNO}_{3} / \mathrm{HBF}_{4}$ method (about 20 wt \% for CS, $\mathrm{LC} \mathrm{FeCr}$, and $\mathrm{HC} \mathrm{FeCr}$, $30 \mathrm{wt} \%$ for SARM 77 and only $1 \mathrm{wt} \%$ for SS) were recovered and analyzed with XRD.

The XRD analyses showed that the IRs consist of spinels (Figure 9). From the different peak positions of spinels, as illustrated in Figure 9, it is clear that the spinel composition differs between the materials, in accordance with the spinels identified in the original bulk samples. For the $\mathrm{HC} \mathrm{FeCr,} \mathrm{two}$ types of spinels are present, the most predominant being a $\mathrm{Cr}$-free spinel (spinel, $\left.\left(\mathrm{Al}_{2} \mathrm{MgO}_{4}\right)\right)$ with a smaller fraction of chromite $\left(\mathrm{Cr}_{2} \mathrm{FeO}_{4}\right)$. The peak pattern of the reference material SARM 77 is quite identical, as expected, since this is the same type of material. For the LC FeCr, broad peaks are present, indicating that both spinel types occur (but with lower contribution of the Cr-free spinel) as well as different compositions in between. For the SS slags, magnesiochromite is identified, whereas in the CS, an intermediate composition of $(\mathrm{Al}, \mathrm{Cr})_{2}(\mathrm{Fe}, \mathrm{Mg}) \mathrm{O}_{4}$ is found.

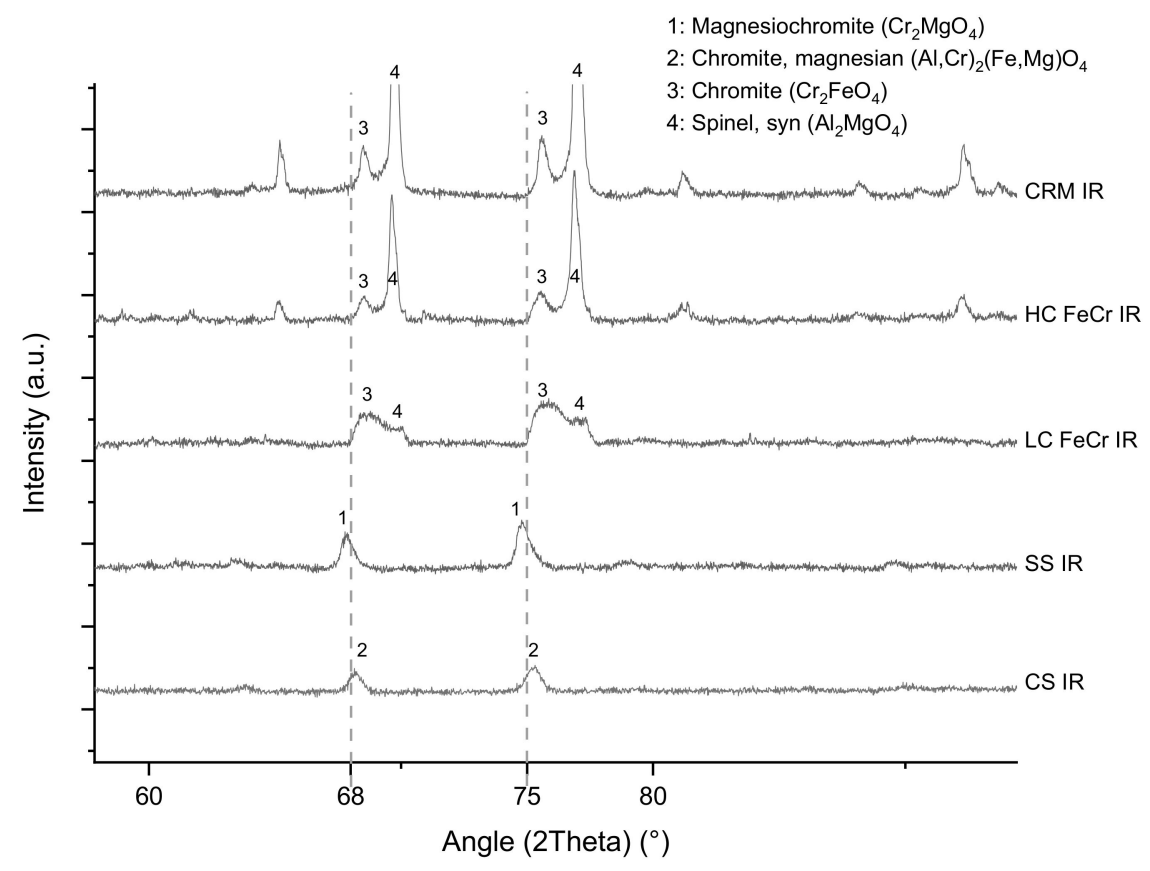

Figure 9. $\mathrm{XRD}$ analysis of insoluble residues after $\mathrm{HCl} / \mathrm{HNO}_{3} / \mathrm{HBF}_{4}$ dissolution.

\section{Discussion}

The detailed multi-analysis characterization has given valuable insight into the speciation of $\mathrm{Cr}$ inside the materials, with implications for the potential recovery. Table 4 summarizes the advantages and disadvantages of each method, and the main characteristics that can be deduced from the single method for the slags. 
Table 4. Summarizing the capabilities of the used methods (MLA is named here vicarious for similar methods such as QEMSCAN, TESCAN TIMA etc.).

\begin{tabular}{ccccc}
\hline Property & Wet Chemistry & XRD & SEM-EDX & MLA \\
\hline $\begin{array}{c}\text { Cr containing } \\
\text { phase identification }\end{array}$ & not possible & $\begin{array}{c}\text { possible (with } \\
\text { restriction of } \\
\text { overlapping peaks) }\end{array}$ & $\begin{array}{c}\text { only chemical } \\
\text { information }\end{array}$ & only chemical information \\
\hline Cr quantification & $\begin{array}{c}\text { determination from } \\
\text { the solution, but } \\
\text { insoluble residues }\end{array}$ & $\begin{array}{c}\text { strongly depending } \\
\text { on correct phase } \\
\text { identification, } \\
\text { backcalculated } \\
\text { "assay" }\end{array}$ & $\begin{array}{c}\text { Cr content for } \\
\text { single grains well } \\
\text { definable }\end{array}$ & $\begin{array}{c}\text { contents make accurate } \\
\text { gradually changing Cr } \\
\text { quantification very hard, } \\
\text { challenging for slags }\end{array}$ \\
\hline spatial distribution & bulk method & bulk method & $\begin{array}{c}\text { zonation becomes } \\
\text { visible }\end{array}$ & $\begin{array}{c}\text { bulk method, basing on } \\
\text { spatially resolved data }\end{array}$ \\
\hline grain information & not possible & not possible & $\begin{array}{c}\text { information } \\
\text { available for a } \\
\text { limited number }\end{array}$ & grain size distribution for \\
different classes
\end{tabular}

Wet chemistry methods give the total amount of $\mathrm{Cr}$ that is present, and thereby the inherent potential for recovery. However, they do not give any insight in the way that this $\mathrm{Cr}$ is distributed, and how accessible it is. A first step to gain deeper insight is XRD, in order to define the mineralogical phases that are present. From this analysis, it was clear that chromium is present in all materials in spinel phases, but the exact composition and quantification is complicated by overlapping peaks in the XRD patterns. Furthermore, XRD is a bulk method, and does not give any information on spatial distribution or particle size, and requires phases to be present in rather high amounts to be identifiable in the diffractogram. The SEM-EDX analysis gave additional insights, such as the occurrence of metallic inclusions and considerable zonation in $\mathrm{Cr}$ content with higher amounts in the spinel core. It also demonstrated the size of the relevant particles, but only on a spot-wise basis. MLA was used to define the grain size distribution for the full sample, divided into different classes.

Apart from providing a different level of information, results from one method can also be used to clarify results from the other. For example, EDX spectra combined with XRD results and expertise on mineral morphology were used to identify the mineral phases observed in SEM. Backcalculation of the chemical composition (from wet chemistry) was needed to verify the XRD results. The uneven distribution of $\mathrm{Cr}$ within the $\mathrm{Cr}$-rich phases (see e.g., Figure 2), observed by SEM, explains the peak shift and overlapping characteristics of the respective phases in the XRD patterns. This gradually changing chemical composition within single phases also hampers the correct quantification of the $\mathrm{Cr}$ content in MLA, as it would require the inclusion of a large number of phases to the mineral list (each for one possible composition in the solid solution). A verification of the MLA data of slags with those restrictions falls out of the scope of this study.

The small size of the Cr-rich particles makes recovery by mineral processing challenging, as a high degree of comminution is needed to reach full mineral liberation. Often, wet separation techniques need to be employed, incurring additional costs for water treatment. Only for the $\mathrm{HC} \mathrm{FeCr} \mathrm{slags} \mathrm{is} \mathrm{the}$ size of the metallic particles sufficient for dry separation.

A reliable quantification of $\mathrm{Cr}$ in the materials before and after recovery is indispensable to calculate recovery efficiency, as well as determine the potential applications of the cleaned-up residue. However, the results of the wet chemical analysis show that many dissolution methods that are commonly used and required by legislation e.g., in Flanders and Germany, are not able to recover all $\mathrm{Cr}$. The main reason for this is that $\mathrm{Cr}$ is mostly present in spinels, which are highly stable phases that are very resistant to attack. The XRD analyses of the insoluble residues after $\mathrm{HCl} / \mathrm{HNO}_{3} / \mathrm{HBF}_{4}$ dissolution confirmed the presence of spinels, thereby supporting the hypothesis that $\mathrm{Cr}$ content is underestimated by incompletely dissolving the spinel phases. The degree of spinel attack can differ strongly based on the dissolution method and spinel composition, as evidenced by the remarkably 
better performance of the $\mathrm{HNO}_{3} / \mathrm{HF} / \mathrm{H}_{2} \mathrm{O}_{2} / \mathrm{H}_{3} \mathrm{BO}_{3}$ method for CS slags than for the other materials. A possible explanation is that the addition of $\mathrm{H}_{2} \mathrm{O}_{2}$ as oxidant manages to attack the Fe spinels present in these slags, but not the $\mathrm{Mg}$ spinels, which are the predominant species in the other slags.

The spinels' high resistance to attack has major implications for the recovery of $\mathrm{Cr}$ from slags, since it is clear that aggressive methods of attack are needed to liberate $\mathrm{Cr}$. Furthermore, the question can be asked of whether methods of analysis based on acid dissolution are relevant to determine $\mathrm{Cr}$ content in slags. This issue, especially for chromites, has been discussed for a long time [28-30]. Already in 1972, Rodgers [30] compared different methods for chrome-rich spinels, stating that their refractory nature and high concentration of $\mathrm{Fe}$ and $\mathrm{Cr}$ makes it difficult to obtain reliable analytical results. $\mathrm{He}$ concluded that peroxide fusion is the best dissolution method for chromite, while the widespread perchloric acid digestions are deficient. The peroxide fusion is commonly applied in the ferrochrome industry, with companies such as PerkinElmer providing dedicated equipment. However, for the reuse of slags, analysis is commonly done according to the standard methods prescribed in environmental legislation, which rely on acid digestion (in the case of Flanders and Germany, even without perchloric acid). Therefore, it is important to be aware that the chromium content obtained with these methods may be an underestimation. Nevertheless, even with the preferred peroxide fusion, it was not possible to recover more than $91 \% \mathrm{Cr}$ of the SARM 77 reference material.

Overall, it can be concluded that a combination of analytical techniques is needed to gain a complete view on the material's characteristics, such as the chemical composition, liberation, and grain-size distribution, and is crucial to further develop processing schemes. Good insight is needed to avoid wrong conclusions based on unsuited analytical techniques. It is indispensable to cross-check and validate the used methods in order gain maximum information for any further treatment and increase its efficiency.

Author Contributions: Conceptualization, L.H. and R.M.; Funding acquisition, L.H.; Investigation, L.H., R.M., P.N., F.K., C.V., and A.M.; Methodology, R.M. and P.N.; Writing-Original draft, L.H., R.M., and A.M.; Writing-Review and editing, L.H., R.M., P.N., F.K., C.V., A.M., and D.A.

Funding: This research was funded by the European Union's Horizon 2020 Research and Innovation program under Grant Agreement no 730471.

Acknowledgments: The authors wish to thank Raymond Kemps for the execution of the SEM analysis, and Myrjam Mertens for the XRD measurements.

Conflicts of Interest: The authors declare no conflict of interest. The funders had no role in the design of the study; in the collection, analyses, or interpretation of data; in the writing of the manuscript, or in the decision to publish the results.

\section{References}

1. Fisher, L.V.; Barron, A.R. The recycling and reuse of steelmaking slags-A review. Resour. Conserv. Recycl. 2019, 146, 244-255. [CrossRef]

2. Pan, S.-Y.; Adhikari, R.; Chen, Y.-H.; Li, P.; Chiang, P.-C. Integrated and innovative steel slag utilization for iron reclamation, green material production and $\mathrm{CO}_{2}$ fixation via accelerated carbonation. J. Clean. Prod. 2016, 137, 617-631. [CrossRef]

3. Euroslag. Statistics. 2016. Available online: https://www.euroslag.com/wp-content/uploads/2019/01/ Statistics-2016.pdf (accessed on 22 October 2019).

4. Niemelä, P.; Kauppi, M. Production, characteristics and use of ferrochromium slags. In Proceedings of the Innovations in Ferry Alloy Industry INFACON XI, New Delhi, India, 18-21 February 2007; pp. 171-179.

5. Sahu, N.; Biswas, A.; Kapure, G.U. A Short Review on Utilization of Ferrochromium Slag. Miner. Process. Extr. Metall. Rev. 2016, 37, 211-219. [CrossRef]

6. ICDA. Statistical Bulletin; ICDA: Paris, France, 2019.

7. Yi, H.; Xu, G.; Cheng, H.; Wang, J.; Wan, Y.; Chen, H. An Overview of Utilization of Steel Slag. Procedia Environ. Sci. 2012, 16, 791-801. [CrossRef]

8. Holappa, L.; Xiao, Y. Slags in ferroalloys production-Review of present knowledge. J. S. Afr. Inst. Min. Metall. 2004, 104, 429-438. 
9. Kotás, J.; Stasicka, Z. Chromium occurrence in the environment and methods of its speciation. Environ. Pollut. 2000, 107, 263-283. [CrossRef]

10. Shen, H.T.; Forssberg, E. An overview of recovery of metals from slags. Waste Manag. 2003, 23, 933-949. [CrossRef]

11. Johnson, J.; Schewel, L.; Graedel, T.E. The contemporary anthropogenic chromium cycle. Environ. Sci. Technol. 2006, 40, 7060-7069. [CrossRef]

12. Garcia-Ramos, E.; Romero-Serrano, A.; Zeifert, B.; Flores-Sanchez, P.; Hallen-Lopez, M.; Palacios, E.G. Immobilization of chromium in slags using $\mathrm{MgO}$ and $\mathrm{Al}_{2} \mathrm{O}_{3}$. Steel Res. Int. 2008, 79, 332-339. [CrossRef]

13. Kuehn, M.; Mudersbach, D. Treatment of liquid EAF-slag from stainless steelmaking to produce environmental friendly construction materials. In Proceedings of the SCANMETII-2nd International Conference on Process Development in Iron and Steelmaking, Lulea, Sweden, 6-9 June 2004; pp. 369-377.

14. Kim, E.; Spooren, J.; Broos, K.; Horckmans, L.; Quaghebeur, M.; Vrancken, K.C. Selective recovery of Cr from stainless steel slag by alkaline roasting followed by water leaching. Hydrometallurgy 2015, 158, 139-148. [CrossRef]

15. Kim, E.; Spooren, J.; Broos, K.; Nielsen, P.; Horckmans, L.; Vrancken, K.C.; Quaghebeur, M. New method for selective $\mathrm{Cr}$ recovery from stainless steel slag by $\mathrm{NaOCl}$ assisted alkaline leaching and consecutive $\mathrm{BaCrO}_{4}$ precipitation. Chem. Eng. J. 2016, 295, 542-551. [CrossRef]

16. Spooren, J.; Kim, E.; Horckmans, L.; Broos, K.; Nielsen, P.; Quaghebeur, M. In-situ chromium and vanadium recovery of landfilled ferrochromium and stainless steel slags. Chem. Eng. J. 2016, 303, 359-368. [CrossRef]

17. Nicolae, M.; Vîlciu, I.; Zaman, F. X-ray diffraction analysis of steel slag and blast furnace slag viewing their use for road construction. UPB Sci. Bull. Ser. B 2007, 69, 99-108.

18. Tsakiridis, P.; Papadimitriou, G.; Tsivilis, S.; Koroneos, C. Utilization of steel slag for Portland cement clinker production. J. Hazard. Mater. 2008, 152, 805-811. [CrossRef] [PubMed]

19. Yildirim, I.Z.; Prezzi, M. Chemical, mineralogical, and morphological properties of steel slag. Adv. Civ. Eng. 2011, 2011, 463638. [CrossRef]

20. Tossavainen, M.; Engstrom, F.; Yang, Q.; Menad, N.; Larsson, M.L.; Bjorkman, B. Characteristics of steel slag under different cooling conditions. Waste Manag. 2007, 27, 1335-1344. [CrossRef] [PubMed]

21. Setién, J.; Hernández, D.; González, J. Characterization of ladle furnace basic slag for use as a construction material. Constr. Build. Mater. 2009, 23, 1788-1794. [CrossRef]

22. Navarro, C.; Diíaz, M.; Villa-Garciía, M.A. Physico-chemical characterization of steel slag. Study of its behavior under simulated environmental conditions. Environ. Sci. Technol. 2010, 44, 5383-5388. [CrossRef]

23. Chaurand, P.; Rose, J.; Domas, J.; Bottero, J.-Y. Speciation of Cr and V within BOF steel slag reused in road constructions. J. Geochem. Explor. 2006, 88, 10-14. [CrossRef]

24. Waligora, J.; Bulteel, D.; Degrugilliers, P.; Damidot, D.; Potdevin, J.; Measson, M. Chemical and mineralogical characterizations of LD converter steel slags: A multi-analytical techniques approach. Mater. Charact. 2010, 61, 39-48. [CrossRef]

25. Doebelin, N.; Kleeberg, R. Profex: A graphical user interface for the Rietveld refinement program BGMN. J. Appl. Crystallogr. 2015, 48, 1573-1580. [CrossRef] [PubMed]

26. Heinig, T.; Bachmann, K.; Tolosana-Delgado, R.; Van Den Boogaart, G.; Gutzmer, J. Monitoring gravitational and particle shape settling effects on MLA sampling preparation. In Proceedings of the IAMG 2015-17th Annual Conference of the International Association for Mathematical Geosciences, Freiberg (Saxony), Germany, 5-13 September; 2015; pp. 200-206.

27. SLACON. Control of Slag Quality for Utilisation in the Construction Industry; SLACON final report RFSR-CT-2012-00006; European Commission: Brussels, Belgium, 2015;

28. Šulcek, Z.; Povondra, P.; Doležal, J.; Langmyhr, F.J. Decomposition procedures in inorganic analysis. CRC Crit. Rev. Anal. Chem. 1977, 6, 255-323. [CrossRef]

29. Chao, T.T.; Sanzolone, R.F. Decomposition techniques. J. Geochem. Explor. 1992, 44, 65-106. [CrossRef]

30. Rodgers, K.A. The decomposition and analysis of chrome spinel. A survey of some published techniques. Mineral. Mag. 1972, 38, 882-889. [CrossRef]

(C) 2019 by the authors. Licensee MDPI, Basel, Switzerland. This article is an open access article distributed under the terms and conditions of the Creative Commons Attribution (CC BY) license (http://creativecommons.org/licenses/by/4.0/). 